\title{
Penciptaan Nilai Fungsi Bisnis: Suatu Konsep Pemberdayaan Agribisnis
}

\section{The Creation of Functional Business VAlue : An Agribusiness EMPOWERMENT CONCEPT}

\author{
${ }^{1}$ Sulistyodewi Nur Wiyono, ${ }^{2}$ Hesty Nurul Utami, ${ }^{3}$ Tuti Karyani \\ 1,2,3 Departemen Sosial Ekonomi Pertanian, Fakultas Pertanian, Universitas Padjadjaran \\ e-mail: ${ }^{1}$ s.wiyono@unpad.ac.id
}

\begin{abstract}
Indramayu regency is one of the food production centers in West Java. Farmers Group Tani Mulus as food production businesses actor in Mundakjaya, Cikedung District, Indramayu Regency has the agricultural business potential to develop, but not optimal yet in utilizing entrepreneurial opportunities in the agrifood supply chain. Based on observations made during the community work Padjadjaran University student from January 2016, the study required community development activities in order Gapoktan Mulus have the direction in the core business development of agricultural products and create a value-added of agricultural products. Community service programs are integrated with learning programs implemented as an effort to develop business functions of Gapoktan Mulus in Mundakjaya. The study use empowerment method through training and facilitating with evaluation. The results of KKNM-PPMD integrative program has a good response, the empowerment participant pleased to participate in every training and facilitating activity.
\end{abstract}

Keywords: community empowerment, value creation, agribusiness

\begin{abstract}
Abstrak. Kabupaten Indramayu merupakan salah satu sentra produksi pangan di Jawa Barat dan memiliki potensi dalam mengembangkan bisnis pertanian yang belum optimal dalam pemanfaatannya terutama pengembangan upaya peluang kewirausahaan masyarakat petani dan pengembangan rantai pasokan agribisnis pangan yang lebih terstruktur. Salah satu pelaku pertanian yang saat ini sedang mencoba mengembangan usaha agribisnis adalah Gabungan Kelompok Tani Mulus sebagai pelaku usaha produksi pangan di Desa Mundakjaya, Kecamatan Cikedung, Berdasarkan hasil pengamatan yang dilakukan pada masa kuliah kerja nyata mahasiswa Universitas Padjadjaran periode Januari tahun 2016, diperlukan kegiatan pemberdayaan masyarakat agar Gapoktan Mulus memiliki arahan dalam pengembangan bisnis pertanian. Program pengabdian kepada masyarakat secara integratif dengan program KKN dilaksanakan sebagai upaya pengembangan fungsi bisnis produksi Gapoktan Mulus Desa Mundakjaya dan penciptaan nilai tambah produk pertanian. Metode pengabdian yang dilakukan adalah pemberdayaan masyarakat melalui pelatihan dan pendampingan yang disertai evaluasi. Hasil program KKNM-PPMD integratif ini mendapat tanggapan yang cukup baik, para peserta pemberdayaan aktif berpartisipasi dalam setiap kegiatan baik pelatihan maupun pendampingan.
\end{abstract}

Kata kunci: pemberdayaan masyarakat, penciptaan nilai, agribisnis

\section{Pendahuluan}

Bisnis pertanian pada rantai pasokan beras di Kecamatan Cikedung, Kabupaten Indramayu, masih bertahan pada sistem konvensional. Pelaku usaha beras di tingkat produsen masih mengandalkan satu jenis usaha yakni mengusahakan padi di lahan sawah sementara lahan kebun dan ladang yang ada belum diolah secara optimal. 
Optimalisasi bisnis pertanian dibutuhkan sebagai langkah menapaki pasar modern. Pasar modern menjadi tujuan dari keterpaduan bisnis pertanian (integrated farming). Pertanian terpadu di komoditas beras, hortikultura, dan peternakan ini yang akan dibangun oleh Gapoktan Mulus di Desa Mundakjaya, Kecamatan Cikedung, Kabupaten Indramayu. Gapoktan Mulus telah banyak mendapat program pendampingan termasuk dari lembaga penelitian di lingkungan Universitas Padjadjaran. Fungsi bisnis pada Gapoktan Mulus harus dapat dioptimalkan agar memberikan kontribusi bagi pendapatan kelompok maupun anggotanya.

Desa Mundakjaya merupakan salah satu desa dari 7 desa yang ada dan berada dalam wilayah Kecamatan Cikedung, Kabupaten Indramayu, dengan jarak tempuh dari pusat Kecamatan $7 \mathrm{KM}$, jarak tempuh dari ibukota kabupaten $30 \mathrm{KM}$, jarak tempuh dari ibukota provinsi $185 \mathrm{KM}$, dan jarak tempuh dari ibukota negara $210 \mathrm{KM}$. Wilayah Desa Mundakjaya terdiri dari 2 blok yaitu Blok Munjul dan Blok Badak yang terbagi dalam 28 Rukun Tetangga (RT) dan 5 Rukun Warga (RW). Selain itu secara administrasi Desa Mundakjaya berbatasan langsung dengan desa-desa yang ada disekelilingnya, diantaranya: sebelah utara Desa Cibereng, sebelah selatan Desa Cikedung Lor, sebelah barat Desa Karangasem, sebelah timur Desa Tempel Kulon.

Masyarakat desa Mundakjaya sebagian besar bermata pencaharian di sektor pertanian yakni usaha budidaya padi sawah, yang pelaksanaannya dalam satu tahun dua kali tanam dengan ketersediaan air masih mencukupi. Keterbatasan ketersediaan air ini terjadi karena secara geografis desa Mundakjaya terletak paling jauh dari saluran pembagi irigasi, terkadang dalam produksinya belum maksimal pada saat musim tanam kedua/gadu. Pada saat kondisi normal kapasitas produksi padi bersih setelah dipotong biaya panen (bawon) mencapai 7 ton/Ha, dan secara keseluruhan produksi padi desa Mundakjaya mencapai 7 ton dikalikan luas keseluruhan lahan yang ada $278 \mathrm{Ha}$ yakni 1.948 ton/musim atau mencapai 3.832 ton/tahun.

PPMD KKNM (Program Pengabdian Masyarakat Dosen-Kuliah Kerja Nyata Mahasiswa) Integratif merupakan kegiatan dimana mahasiswa bersama dengan DPL (Dosen Pembimbing Lapangan) dapat mengabdikan ilmunya secara lebih leluasa sehingga bisa lebih berdayaguna dan berhasil guna. PPMD KKNM-Integratif merupakan program pembelajaran mahasiswa dan Dosen dalam bentuk KKN Mahasiswa terintegrasi dengan program PPMD yang menekankan pada prinsip Belajar Bersama Masyarakat.

Beberapa permasalahan yang ditemukan antara lain: 1) Gapoktan Mulus memiliki banyak fungsi bisnis yang akan dijalankan namun belum terarah, dan 2) Beberapa anggota Gapoktan Mulus belum mendapatkan pengetahuan dan ketrampilan mengenai nilai tambah produk pertanian yang menjadi potensi di wilayahnya.

Tujuan yang ingin dicapai dari pemberdayaan ini, antara lain: 1) Peserta pemberdayaan mengetahui informasi mengenai core (inti) bisnis yang dimiliki dan arah pengembangannya, dan 2) Peserta pemberdayaan mendapatkan pengetahuan dan keterampilan mengenai nilai tambah produk pertanian sehingga dapat memanfaatkan potensi produksi yang dimiliki.

\section{Metodologi pelaksanaan}

Sumodiningrat (1999) menjelaskan bahwa pemberdayaan masyarakat merupakan upaya untuk mamandirikan masyarakat lewat perwujudan potensi kemampuan yang dimiliki. Pemberdayaan masyarakat terdiri dari 2 (dua) kelompok yang saling terkait, antara lain masyarakat sebagai pihak yang diberdayakan, dan 
kelompok kedua sebagai pihak yang menaruh kepedulian, berperan sebagai pihak yang memberdayakan.

Chambers (1995) memberikan paradigma baru pembangunan dalam pemberdayaan masyarakat, yakni "people centered, participatory, empowering, and sustainable". Masyarakat tidak lagi sebagai objek pembangunan, namun merupakan subjek dari upaya pembangunannya sendiri.

Kegiatan ini membutuhkan partisipasi aktif dari perwakilan masyarakat yang menjadi peserta pemberdayaan, yakni 10 orang pengurus dari Gapoktan Mulus dan 10 anggota Gapoktan Mulus yang merupakan ketua dari beberapa kelompok tani yang tergabung dalam Gapoktan Mulus. Pengambilan peserta pemberdayaan menggunakan pertimbangan waktu, biaya, dan tempat yang dimiliki tim pemberdaya. Ketua kelompok yang terlibat diharapkan akan mampu meneruskan informasi kepada seluruh anggotanya.

Metode pengabdian yang dilakukan adalah pemberdayaan masyarakat melalui pelatihan yang disertai monitoring. Peserta kegiatan PPMD ini merupakan anggota dan pengurus Gapoktan yang termasuk usia dewasa 25-45 tahun sehingga metode penyampaian materi pelatihan yang digunakan adalah metode pembelajaran orang dewasa melalui teknik diskusi.

Malcolm Knowles (1986) dalam Suprijanto (2008), menyebutkan ada 4 (empat) prinsip pembelajaran orang dewasa, yakni:

1. Orang dewasa perlu terlibat dalam merancang dan membuat tujuan pembelajaran. Mereka mesti memahami sejauh mana pencapaian hasilnya.

2. Pengalaman adalah asas aktivitas pembelajaran. Menjadi tanggung jawab peserta didik menerima pengalaman sebagai suatu yang bermakna.

3. Orang dewasa lebih berminat mempelajari perkara-perkara yang berkaitan secara langsung dengan kerja dan kehidupan mereka.

4. Pembelajaran lebih tertumpu pada masalah (problem-centered) dan membutuhkan dorongan dan motivasi.

Menurut Sumarsono (2009), pelatihan merupakah salah satu faktor yang penting dalam pengembangan sumber daya manusia. Pelatihan tidak hanya menambah pengetahuan, tetapi juga meningkatkan ketrampilan bekerja, dengan demikian dapat meningkatkan produktivitas kerja. Pelaksanaan kegiatan pelatihan membutuhkan monitoring sebagai langkah selanjutnya dalam upaya pendampingan. Sebuah program pemberdayaan masyarakat tidak lain merupakan integrasi dari berbagai penggal aktivitas (sub-system) yang dimulai dari proses perencanaan kegiatan, pelaksanaan kegiatan, monitoring dan evaluasi, serta tindak lanjut dari kegiatan (Ma'ruf, 2000). Ma'ruf (2000) juga mengungkapkan kegiatan monitoring dan evaluasi merupakan proses refleksi atas apa yang telah dilakukan dengan apa yang direncanakan.

Jadwal kegiatan pelaksanaan PPMD dimulai pada bulan Januari dan berakhir di bulan April 2016 di Desa Mundakjaya, Kecamatan Cikedung, Kabupaten Indramayu. Tahapan pelaksanaan dapat dilihat pada Tabel berikut.

Tabel 1. Tahapan Pelaksanaan PPMD

\section{No. Rencana Kegiatan Deskripsi}

1. Tahap persiapan:

- Pembuatan proposal

- Pembuatan undangan pelatihan
Tim PPMD bertugas dalam pembuatan

proposal kegiatan, kebutuhan surat

perizinan, pembuatan modul materi

penyuluhan dan simulasi. Peserta turut 
No. Rencana Kegiatan

- Pembuatan modul pelatihan

- Pembuatan materi simulasi

2. Tahap pelaksanaan:

- Pemberian materi pelatihan

- Pemberian materi simulasi secara partisipatif

3. Tahap monitoring:

Memantau perkembangan hasil pelatihan partisipatif setelah pelaksanaan dan sebelum dilakukan penilaian

4. Tahap evaluasi:

Pemberian umpan balik dengan cara berdiskusi setelah proses monitoring

5. Tahap pelaporan:

- Menyusun laporan kegiatan KKNM PPMD Integratif

- Memberikan laporan hasil kegiatan
Deskripsi

membantu memberikan informasi yang dibutuhkan

Tim PPMD berperan dalam penyampaian materi pelatihan dan simulasi yang dapat mengeksplorasi minat dan kemampuan peserta pelatihan. Peserta berpartisipasi aktif dalam pelaksanaan PPMD Tim PPMD bertugas memantau perkembangan yang dicapai oleh peserta pelatihan setelah pelaksanaan kegiatan. Peserta berperan dalam mengimplementasi rencana bisnis pasca pelatihan.

Tim PPMD menyelenggarakan diskusi dalam proses penilaian terhadap hasil pelatihan. Peserta dapat memanfaatkan pelaksanaan diskusi dengan cermat dan tepat.

DPL dan tim PPMD menyelesaikan laporan kegiatan KKNM PPMD Integratif dengan sebaik-baiknya

\section{Hasil dan Pembahasan}

Pemberdayaan dalam pengembangan fungsi bisnis sangat diperlukan mengingat Gapoktan Mulus telah banyak melakukan proses bisnis namun tidak didukung dengan tingkat pengetahuan dan kemampuan dari pengurus yang menjadi pelaku utama bisnis tersebut. Pengembangan potensi petani dalam mengoptimalkan fungsi bisnis yang dijalankan harus dapat menjadi keuntungan komparatif di wilayahnya. Petani dituntut untuk mengasah naluri pengusaha dalam menjalankan usahanya dan mengidentifikasi potensi yang dimiliki individu maupun kelompoknya di bidang usaha pertanian lainnya sehingga tercipta bisnis pertanian terpadu (integrated farming). Tiga pilar yang dibangun dalam pemberdayaan ini dilatarbelakangi kapasitas dari tim Pengabdian kepada Masyarakat yang terdiri dari ahli manajemen operasional agribisnis, ahli pemasaran, dan ahli pembiayaan agribisnis.

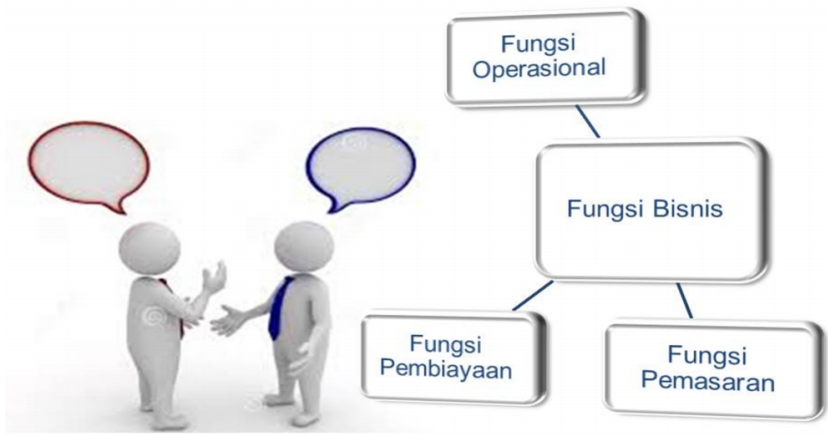

Gambar 1. Tiga bidang pemberdayaan fungsi bisnis Gapoktan Mulus 
Berdasarkan konsep dan definisi dari manajemen agribisnis, maka keberhasilan dan kelancaran setiap sub sistem yang ada di dalam sistem agribisnis dipengaruhi oleh pelaksanaan fungsi bisnis di dalam manajemen usaha itu sendiri. Fungsi bisnis di dalam manajemen usaha meliputi fungsi bisnis produksi, fungsi bisnis keuangan, fungsi bisnis sumber daya manusia, fungsi bisnis pemasaran, dan fungsi bisnis riset dan pengembangan. Keberadaan fungsi bisnis di dalam sebuah usaha berbeda - beda tergantung dari skala usaha dan kebutuhan dari masing - masing industri. Semakin besar skala usaha dapat diasumsikan usaha tersebut akan memiliki fungsi bisnis yang semakin kompleks karena kebutuhan pengelolaan asset dan jeraring yang semakin luas, begitu pun sebaliknya.

Bidang operasional berperan dalam penyelenggaraan proses produksi usaha. Proses operasional yang efektif dengan lebih memaksimalkan fungsi persediaan, transportasi, dan standar prosedur kualitas akan menekan biaya produksi sehingga memberikan keuntungan lebih besar bagi suatu perusahaan.

Pemasaran pertanian dapat didefinisikan sebagai jumlah kegiatan bisnis yang ditujukan untuk memberi kepuasan dari barang atau jasa yang dipertukarkan kepada konsumen atau pemakai dalam bidang pertanian, baik input maupun produk pertanian (Gumbira-Said, Intan, 2001). Sehingga pemasaran pertanian berfungsi pada proses input produk pertanian sampai dengan produk hasil akhir pertanian.

Sementara itu bisnis pertanian yang berkelanjutan artinya bisnis pertanian tersebut harus mampu memberikan keberlangsungan usaha secara jangka panjang baik berkelanjutan secara lingkungan, pendapatan, maupun secara sosial. Melalui model agribisnis yang kreatif dengan menggunakan konsep pertanian berkelanjutan maka para pengusaha agribisnis harus mampu menciptakan sesuatu yang baru dengan penuh daya cipta yang diperoleh dari pemikiran dan keterampilan sesorang untuk menciptakan sesuatu yang berbeda dari yang lain sehingga mempunyai keunggulan atau keunikan sebagai diferensiasi bisnis di dalam persaingan yang semakin mengglobal. Konsep pertanian seperti ini akan serta merta menggiring setiap fungsi bisnis di dalam bisnis pertanian yang dijalankan terutama model rantai pasok dan pemasaran yang semakin modern dengan mengusung efisiensi dan efektifitas.

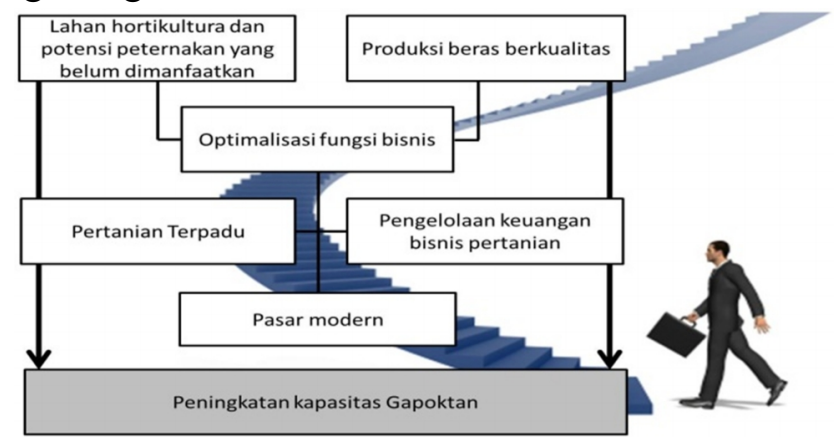

Gambar 2. Langkah Pemberdayaan Gapoktan

Memahami definisi agribisnis yang ada, bisnis pertanian merupakan wilayah yang sangat luas dalam pengembangannya. Semakin luasnya bisnis pertanian yang dijalankan maka akan semakin besar peluang meningkatkan pendapatan pelaku usaha pertanian. Fungsi bisnis ini yang belum dioptimalkan oleh petani sebagai pelaku usaha agribisnis. Orientasi produsen padi telah mengikat petani padi untuk mempertahankan sistem konvensional dalam rantai pasokan beras di Kabupaten Indramayu, sebagai salah satu sentra produksi beras di Jawa Barat. 
Pemberian materi mengenai pemasaran dan operasional agribisnis dipandang dapat menjadi penggerak motivasi anggota dan pengurus Gapoktan Mulus. Materi praktek melalui pencatatan keuangan yang mencakup seluruh aktivitas bisnis didalamnya diharapkan dapat meningkatkan pengetahuan dalam pengelolaan bisnis pertanian.

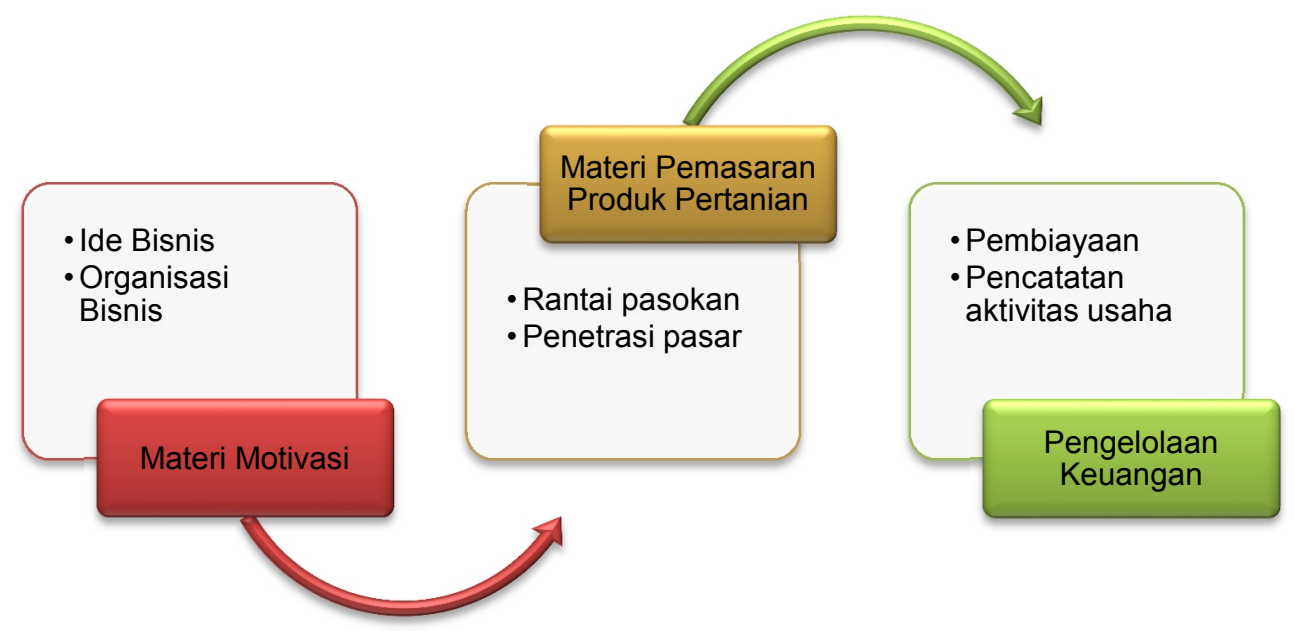

Gambar 3. Materi Pelatihan Aplikasi Fungsi Bisnis

Kekuatan Gapoktan Mulus ada dalam usia para pengurusnya yang masih tergolong petani muda dibawah 40 tahun. Kekuatan ini yang menjadi daya dukung keberhasilan program kegiatan yang dilaksanakan Gapoktan Mulus sejak beberapa tahun terakhir. Pemikiran inovasi yang dimiliki Ketua Gapoktan dinilai mampu membangun kapasitas Gapoktan Mulus mencapai tujuan lebih tinggi. Keterlibatan peserta dalam kegiatan pemberdayaan ini dapat dilihat pada tabel berikut:

Tabel 2. Keterlibatan Peserta dalam kegiatan Pemberdayaan di Desa Mundakjaya No. Kegiatan Keterlibatan Masyarakat dalam kegiatan

1. Tahap pelaksanaan:

Pemberian materi pelatihan

Peserta pemberdayaan berpartisipasi

aktif dalam pelatihan penciptaan

nilai tambah produk pertanian

2. Tahap pendampingan:

Peserta pemberdayaan memiliki

Memantau perkembangan hasil

tugas dalam mengimplementasikan pelatihan partisipatif setelah rencana bisnis (Business plan) pasca pelaksanaan dan sebelum pelatihan dilakukan penilaian

3. Tahap evaluasi:

Pemberian umpan balik dengan cara berdiskusi setelah proses pendampingan

Peserta pemberdayaan
memanfaatkan proses diskusi dengan
tim pemberdaya dan diharapkan
peserta menjadi berdaya bisnis dalam
usaha pertanian yang dimiliki

Pelaksanaan pengabdian kepada masyarakat ini diharapkan seluruh peserta pelatihan mendapatkan pengetahuan baru dan pendampingan sebagai pencerahan usaha yang dimiliki. Pengembangan fungsi bisnis dinilai tepat untuk mengisi ruang pengetahuan dan praktek bagi pengurus dan anggota Gapoktan. 
Pada pelaksanaan pelatihan dan proses pendampingan (monitoring) maka model kegiatan yang tercantum dalam tujuan dan capaian hasil kegiatan PPMD ini diharapkan dapat diwujudkan dalam Gambar berikut:

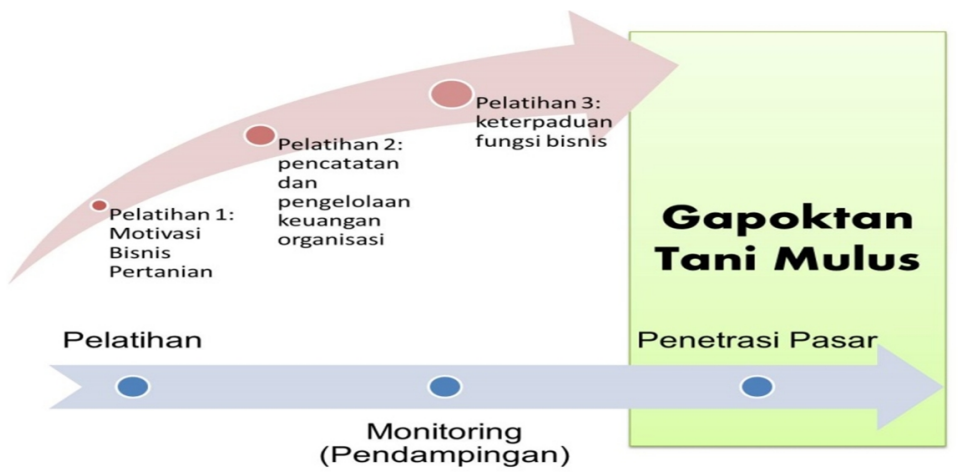

Gambar 4. Model pemberdayaan masyarakat yang dilakukan

Berdasarkan data responden yang telah diolah saat pendampingan, diketahui perubahan kondisi setelah adanya proses pelatihan mengenai fungsi bisnis dan nilai tambah produk pertanian. Lebih jelasnya dapat dilihat pada tabel berikut.

Tabel 3. Indikator Kegiatan dan Perubahan Pasca Kegiatan PPM

\begin{tabular}{|c|c|c|c|}
\hline No. & Indikator & $\begin{array}{c}\text { Base Line } \\
\text { (sebelum kegiatan) }\end{array}$ & $\begin{array}{c}\text { Pencapaian } \\
\text { (setelah kegiatan) }\end{array}$ \\
\hline 1 & $\begin{array}{l}\text { Keinginan melakukan } \\
\text { perubahan }\end{array}$ & $\begin{array}{l}\text { Peserta pendampingan } \\
\text { kurang berminat untuk } \\
\text { berubah menuju suatu hal } \\
\text { baru yang tidak pasti }\end{array}$ & $\begin{array}{l}\text { Peserta pendampingan } \\
\text { berminat untuk berubah } \\
\text { dengan asumsi } \\
\text { perubahan untuk } \\
\text { menjadi lebih baik }\end{array}$ \\
\hline 2 & $\begin{array}{l}\text { Pengetahuan dan } \\
\text { keterampilan dalam } \\
\text { proses pasca panen }\end{array}$ & $\begin{array}{l}\text { Peserta pemberdayaan tidak } \\
\text { menganggap pentingnya } \\
\text { kegiatan pasca panen dan } \\
\text { nilai produk pertanian }\end{array}$ & $\begin{array}{l}\text { Peserta pendampingan } \\
\text { merasa perlu untuk } \\
\text { meningkatkan } \\
\text { pengetahuan dalam } \\
\text { kegiatan pasca panen } \\
\text { dan nilai tambah } \\
\text { produk pertanian }\end{array}$ \\
\hline 3 & $\begin{array}{l}\text { Motivasi } \\
\text { kewirausahaan (sense } \\
\text { of entrepreneurship) }\end{array}$ & $\begin{array}{l}\text { Tidak adanya keinginan } \\
\text { untuk berwirausaha } \\
\text { mengembangkan agribisnis } \\
\text { selain komoditas padi }\end{array}$ & $\begin{array}{l}\text { Mulai muncul } \\
\text { keinginan untuk } \\
\text { membangun jaringan } \\
\text { rantai pasokan } \\
\text { pertanian terpadu } \\
\text { (integrated farming) }\end{array}$ \\
\hline
\end{tabular}

Pelaksanaan PPMD didasarkan pada hasil pengamatan yang dilakukan oleh mahasiswa program KKN di desa Mundakjaya. Kegiatan PPMD sendiri merupakan kebutuhan nyata dari masyarakat setempat sehingga masyarakat mendapatkan manfaat dari pelaksanaan kegiatan PPMD ini.

Pelaksanaan PPM dipersiapkan bersama antara mahasiswa, pengurus Gapoktan, dan tim dosen PPMD. Penentuan waktunya dilakukan menyesuaikan dengan aktivitas anggota Gapoktan yang diketahui kegiatan PPMD ini bersamaan dengan waktu tanam. Koordinasi dilakukan secara tatap mata dan komunikasi melalui ponsel agar tepat sasaran dan tepat waktu. 


\section{4 | Sulistyodewi Nur Wiyono, et al.}

Pada setiap kegiatan PPMD dihadiri oleh seluruh tim dosen dan pengurus Gapoktan. Audiens anggota kelompok bergantian hadir agar proses transfer ilmu pengetahuan tersebar merata. Penyampaian materi pelatihan selain menggunakan media proyektor (infocus) juga alat simulasi berupa maket pertanian terpadu yang telah disediakan sebelumnya. Praktek langsung dilakukan pada pelatihan pencatatan keuangan. Hasil pelaksanaan kegiatan diuraikan pada tabel berikut:

Tabel 1. Hasil Pelaksanaan Kegiatan PPMD

\begin{tabular}{|c|c|c|}
\hline No. & Program & Hasil Kegiatan \\
\hline 1 & Pengamatan & $\begin{array}{l}\text { Pengamatan dilakukan pada saat monitoring } \\
\text { pelaksanaan KKN periode Januari } 2016\end{array}$ \\
\hline 2 & Identifikasi masalah & $\begin{array}{l}\text { Permasalahan yang muncul berdasarkan diskusi } \\
\text { bersama tokoh masyarakat diarahkan pada } \\
\text { aktifitas Gapoktan yang menjadi program } \\
\text { unggulan Desa Mundakjaya. Aktifitas Gapoktan } \\
\text { terdiri dari proses produksi, operasional, dan } \\
\text { pemasaran. }\end{array}$ \\
\hline 3 & $\begin{array}{l}\text { Pemilihan kelompok } \\
\text { sasaran }\end{array}$ & $\begin{array}{l}\text { Pada rantai aktifitas Gapoktan, pengurus dinilai } \\
\text { menjadi roda produksi Gapoktan. Peningkatan } \\
\text { ketrampilan pada pengurus Gapoktan diharapkan } \\
\text { mampu menjadi motivasi bagi pengurus dan } \\
\text { anggota dalam menjalankan fungsi bisnis produksi } \\
\text { beras. }\end{array}$ \\
\hline 4 & $\begin{array}{l}\text { Pemetaan kebutuhan } \\
\text { kelompok sasaran }\end{array}$ & $\begin{array}{l}\text { Kebutuhan Gapoktan Mulus di Desa Mundakjaya } \\
\text { antara lain motivasi, ketrampilan pencatatan } \\
\text { usaha, dan wawasan pemasaran ke pasar modern. }\end{array}$ \\
\hline 5 & $\begin{array}{l}\text { Koordinasi pelaksanaan } \\
\text { pelatihan }\end{array}$ & $\begin{array}{l}\text { Koordinasi dilakukan antara tim PPMD Unpad, } \\
\text { Sekretaris Desa Mundakjaya, Ketua Gapoktan dan } \\
\text { Ketua Karang Taruna Desa Mundakjaya. }\end{array}$ \\
\hline 6 & $\begin{array}{l}\text { Penyusunan materi } \\
\text { pelatihan }\end{array}$ & $\begin{array}{l}\text { Materi pelatihan disusun oleh tim PPMD } \\
\text { berdasarkan latar belakang keahlian yang dimiliki } \\
\text { antara lain materi pemasaran dan materi keuangan } \\
\text { usaha. }\end{array}$ \\
\hline 7 & $\begin{array}{l}\text { Pembuatan alat peraga } \\
\text { (simulasi) pelatihan }\end{array}$ & $\begin{array}{l}\text { Pembuatan alat peraga sebagai materi operasional } \\
\text { yang dirancang agar memberikan gambaran sistem } \\
\text { produksi pertanian terpaadu melalui model/maket. }\end{array}$ \\
\hline 8 & $\begin{array}{l}\text { Persiapan pelaksanaan } \\
\text { pelatihan }\end{array}$ & $\begin{array}{l}\text { Persiapan pelaksanaan pelatihan dibantu oleh } \\
\text { rekan-rekan peserta KKNM sebagai kegiatan } \\
\text { kemasyarakatan di Desa Mundakjaya. }\end{array}$ \\
\hline 9 & Pelatihan I & $\begin{array}{l}\text { Pelatihan I mengenai motivasi usaha dihadiri oleh } \\
\text { pengurus dan anggota wanita tani dari Gapoktan } \\
\text { Mulus. Peserta pelatihan I merasa lebih } \\
\text { bersemangat lagi untuk dapat mengoptimalkan } \\
\text { usaha yang dimiliki dan memulai usaha yang akan } \\
\text { dilaksanakan. }\end{array}$ \\
\hline 10 & Pelatihan II & $\begin{array}{l}\text { Pelatihan II memberikan gambaran mengenai } \\
\text { rantai pasokan beras di Jawa Barat yang telah } \\
\text { memasuki pasar modern sebagai upaya } \\
\text { meningkatkan pendapatan usaha taninya. Pada } \\
\text { pelatihan ini diberikan simulasi dengan }\end{array}$ \\
\hline
\end{tabular}




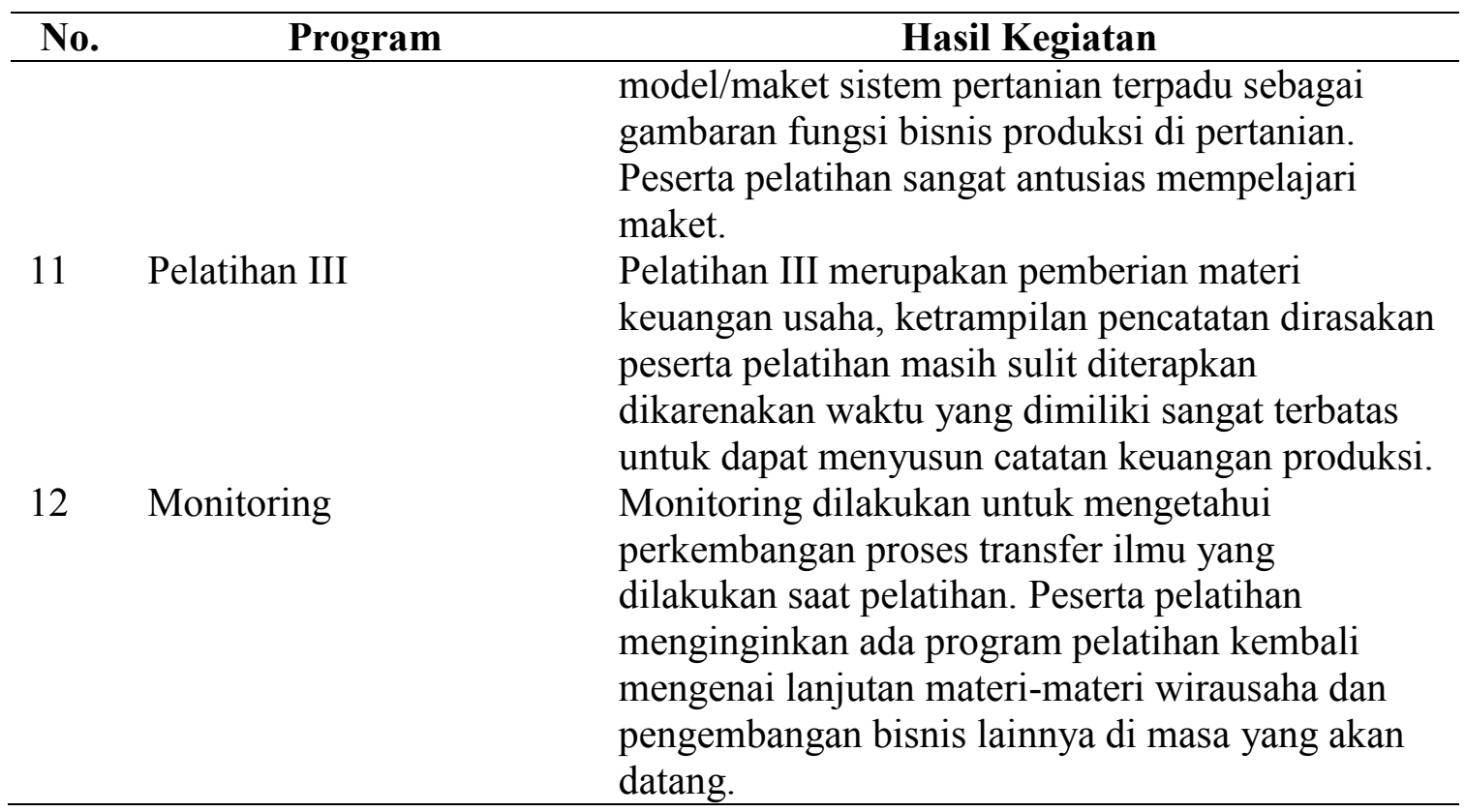

Hasil seluruh kegiatan pelatihan yang dilaksanakan, peserta memberikan respon positif dan antusias dalam menerima materi. Indikator pelaksanaan kegiatan dan perubahannya dapat dilihat pada Tabel berikut:

Tabel 2 Indikator Kegiatan dan Perubahan Pasca Kegiatan PPM

\begin{tabular}{|c|c|c|c|}
\hline No. & Indikator & $\begin{array}{c}\text { Base Line } \\
\text { (sebelum kegiatan) }\end{array}$ & $\begin{array}{c}\text { Pencapaian } \\
\text { (setelah kegiatan) }\end{array}$ \\
\hline 1 & $\begin{array}{l}\text { Motivasi untuk } \\
\text { melakukan perubahan }\end{array}$ & $\begin{array}{l}\text { Peserta pendampingan } \\
\text { kurang berminat untuk } \\
\text { berubah menuju suatu } \\
\text { hal baru yang tidak } \\
\text { pasti }\end{array}$ & $\begin{array}{l}\text { Peserta pendampingan } \\
\text { berminat untuk berubah } \\
\text { dengan asumsi perubahan } \\
\text { untuk menjadi lebih baik }\end{array}$ \\
\hline 2 & $\begin{array}{l}\text { Keinginan untuk } \\
\text { meningkatkan } \\
\text { cakupan bisnis }\end{array}$ & $\begin{array}{l}\text { Peserta pendampingan } \\
\text { menganggap tidak perlu } \\
\text { untuk melakukan } \\
\text { perluasan cakupan } \\
\text { bisnis }\end{array}$ & $\begin{array}{l}\text { Peserta pendampingan } \\
\text { memiliki keinginan sendiri } \\
\text { untuk memperluas jaringan } \\
\text { dan cakupan bisnis }\end{array}$ \\
\hline 3 & $\begin{array}{l}\text { Tingkat pengetahuan } \\
\text { dan keterampilan } \\
\text { dalam proses pasca } \\
\text { panen dan pemasaran } \\
\text { bertambah }\end{array}$ & $\begin{array}{l}\text { Peserta pendampingan } \\
\text { tidak menganggap } \\
\text { pentingnya kegiatan } \\
\text { pasca panen dan } \\
\text { penetrasi pemasaran }\end{array}$ & $\begin{array}{l}\text { Peserta pendampingan } \\
\text { merasa perlu untuk } \\
\text { meningkatkan pengetahuan } \\
\text { dalam kegiatan pasca panen } \\
\text { dan penetrasi pasar }\end{array}$ \\
\hline 4 & $\begin{array}{l}\text { Tingkat partisipatif } \\
\text { dalam kegiatan } \\
\text { pelatihan dan } \\
\text { pendampingan cukup } \\
\text { tinggi }\end{array}$ & $\begin{array}{l}\text { Peserta pendampingan } \\
\text { hanya hadir sebagai } \\
\text { peserta pasif }\end{array}$ & $\begin{array}{l}\text { Peserta pendampingan } \\
\text { menjadi peserta aktif dalam } \\
\text { jangka panjang }\end{array}$ \\
\hline 5 & $\begin{array}{l}\text { Kemampuan } \\
\text { pengelolaan keuangan } \\
\text { usaha meningkat }\end{array}$ & $\begin{array}{l}\text { Pengurus Gapoktan } \\
\text { tidak seluruhnya } \\
\text { memahami pengelolaan } \\
\text { keuangan dan }\end{array}$ & $\begin{array}{l}\text { Pengurus Gapoktan } \\
\text { keseluruhan memahami } \\
\text { bagaimana pengelolaan } \\
\text { keuangan yang tepat }\end{array}$ \\
\hline
\end{tabular}




\begin{tabular}{llll}
\hline No. & \multicolumn{1}{c}{ Indikator } & \multicolumn{1}{c}{$\begin{array}{c}\text { Base Line } \\
\text { (sebelum kegiatan) }\end{array}$} & \multicolumn{1}{c}{$\begin{array}{c}\text { Pencapaian } \\
\text { (setelah kegiatan) }\end{array}$} \\
\hline 6 & pembiayaan & \\
Pengetahuan & Peserta pendampingan & Peserta pendampingan \\
mengenai fungsi & tidak mengetahui fungsi & mengetahui fungsi bisnis \\
bisnis dapat & bisnis yang secara & secara terpadu dan \\
diterapkan melalui & menyeluruh & mengaplikasikannya sebagai \\
penetrasi pasar & & upaya penetrasi pasar \\
\hline
\end{tabular}

\section{Kesimpulan dan Saran}

Kegiatan pelaksanaan PPMD ini telah memberikan manfaat masyarakat Desa Mundakjaya pada umumnya dan Gapoktan Mulus pada khususnya. Manfaat tersebut dirasakan masyarakat dengan bertambahanya pengetahuan masyarakat yang dapat meningkatkan pendapatan dan kapasitas daya saing bisnis masyarakat mengenai fungsi bisnis, pentingnya pencatatan keuangan dan rantai pasokan komoditas pertanian.

Kegiatan PPMD ini diharapkan menjadi motor penggerak aktivitas masyarakat Desa Mundakjaya yang nantinya akan berpartisipasti aktif di tingkat Kabupaten hingga nasional. Seiring dengan partisipasi aktif tersebut juga diharapkan dari hasil pelatihan ini, masyarakat mampu memberikan kontribusi terhadap daya saing pelaku agribisnis di Desa Mundakjaya untuk mewujudkan peningkatan kesejahteraan desa.

\section{Ucapan terimakasih}

Terimakasih kepada Direktorat Penelitian dan Pengabdian kepada Masyarakat Universitas Padjadjaran atas dukungan dana hibah PPMD-KKNM Integratif periode Januari-Maret 2016.

\section{Daftar pustaka}

Chambers, R (1985). Rural Development: Putting The Last First. London, New York: Longman.

Gumbira-Said, E., A. Harizt Intan (2001). Manajemen Agribisnis. Jakarta: Ghalia Indonesia dan MMA IPB.

Sumarsono (2009). Ekonomi Sumber Daya Manusia, Teori dan Kebijakan Publik. Yogyakarta : Graha Ilmu.

Sumodiningrat, Gunawan (1999). Pemberdayaan Masyarakat dan Jaring pengaman Sosial. Jakarta: Gramedia Pustaka Utama

Suprijanto (2008). Pendidikan Orang Dewasa dari Teori hingga Aplikasi. Jakarta: PT Bumi Aksara.

Ma'ruf, Ahmad (2000). Arti Penting Evaluasi dan Monitoring pada Program Pemberdayaan Masyarakat. Aplikasia, Jurnal Aplikasi Ilmu-ilmu Agama Vol.1 No.1 Desember 2000. 